\title{
лІтопис подІй
}

DOI: https://dx.doi.org /10.18524/2312-6809.2018.27.146612

\section{ШЛЯХАМИ НАУКОВОГО ПОШУКУ (ОДЕСА, 4-5 ЖОВТНЯ 2018 РОКУ)}

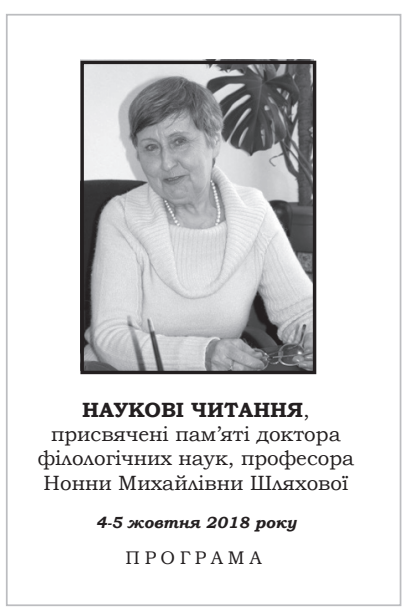

2018 року виповнилося б 85 років доктору філологічних наук, професору Шляховій Нонні Михайлівні. Кафедра теорії літератури та компаративістики, безперечним лідером якої 26 років була Нонна Михайлівна, стала ініціатором проведення Наукових читань, які відбулися 4-5 жовтня 2018 року у приміщенні Культурного центру Наукової бібліотеки Одеського національного університету імені I. І. Мечникова.

Конференцією було об'єднано представників усіх кафедр філологічного факультету не тільки тому, що до історії кожної з них Нонна Михайлівна мала безпосереднє відношення, а й у більшій мірі через різноаспектну проблематику іiі наукових зацікавлень. I літературознавці, і мовознавці завжди знаходили пункти перетину теоретичних ідей під час традиційних факультетських круглих столів та інших креативних івентів, організованих Шляховою Н. М.

У межах Наукових читань відбулась презентація книжково-ілюстративної виставки «Шляхами наукового пошуку». Завдяки наполегливій і кропіткій праці співробітників Наукової бібліотеки ОНУ імені I. I. Мечникова, у першу чергу iї директора М. О. Подрєзової, усі присутні мали змогу ознайомитися із науковими працями Нонни Михайлівни, виданнями, які вона редагувала, а також раритетними довідковими книгами. Усі охочі скористалися нагодою потримати в руках і погортати друковані праці професора Шляхової Н. М.: від автореферату іiї дисертації і до останніх публікацій, які побачили світ уже після смерті автора.

(c) Коробкова Н., 2018 
Форматом проведення заходу було передбачено такий календар роботи: по-перше, меморіальний блок, який містить калейдоскоп спогадів про Нонну Михайлівну; по-друге, власне виголошення наукових доповідей, яке відбулося в секціях. Наукову полеміку було розгорнуто в межах п'яти напрямків, які відображають сферу зацікавлень професора Шляхової. Це, зокрема, психологія творчості, авторські іпостасі, рецептивно-інтерпретаційні параметри функціонування художнього твору, а також комплекс наукових рефлексій, які постали внаслідок розробки окремих проблем, зумовлених ідеєю діалогічності мистецтва. На пленарному засіданні були присутні донька Нонни Михайлівни доктор філологічних наук, доцент, завідувач кафедри прикладної лінгвістики Національного університету «Одеська юридична академія» М. В. Мамич та онука кандидат юридичних наук О. В. Шевченко-Бітенська. Відрадним є й те, що до участі в конференції долучилися молоді колеги: не лише аспіранти, але й магістранти і студенти бакалаврату.

Пленарне засідання було відкрито доповіддю доктора філологічних наук, професора кафедри теорії літератури та компаративістики, декана філологічного факультету Черноіваненка Є. М. на тему «Нонна Михайлівна Шляхова: творення долі». «Доля Нонни Михайлівни стала частиною долі факультету, який вона так любила», - зауважив доповідач, підкреслюючи серед багатьох факторів, що складають феномен Н. М. Шляхової, іiї безмежну людяність і щирість, які прикметно характеризують Нонну Михайлівну як багаторічного декана факультету.

Про вирішальну роль професора Н. М. Шляхової у власній науковій долі згадувала Коробкова Н. К., кандидат філологічних наук, доцент, завідувач кафедри теорії літератури та компаративістики, адже усі іiї наукові студії (від курсових робіт і до дисертаційного дослідження) були написані під керівництвом цієї людини - Мудрого і Найкращого Вчителя.

Про Нонну Михайлівну як педагога і методиста розповів кандидат філологічних наук, доцент кафедри теорії літератури та компаративістики Пащенко М. В. Зокрема йшлося про давні міжнародні зв'язки філологічного факультету ОНУ імені І. І. Мечникова. Виклад маловідомих широкому колу слухачів фактів тривалої, продуктивної і цікавої роботи Нонни Михайлівни у літньому таборі мовної підготовки в Угорщині супроводжувався грунтовною фотовізуалізацією, за 
допомогою якої у повній мірі було передано аспекти інтенсифікації процесу навчання мови в актуальній сьогодні ігровій формі.

Член Національної спілки журналістів України, член Одеської гільдії власних кореспондентів центральних газет, член Всесвітнього Союзу франкомовної преси (Париж) Щербань М. Т. поділився з присутніми власними спогадами і враженнями про виступ із доповіддю щодо методики викладання журналістики на неординарному заході для світової журналістики - Міжнародному конгресі у Швейцарії, відрядження до якої було б неможливим без сприяння Нонни Михайлівни.

Полтавчук В. Г., кандидат філологічних наук, доцент кафедри української літератури, член Національної спілки письменників України розкрив феномен Нонни Шляхової як співавтора гімну філологічного факультету. Принагідно нагадаємо, що цей гімн у виконанні Миколи Свидюка та університетської хорової капели, у записі, відкриває усі урочисті заходи. Уточнимо, що автором музики є народний артист України Микола Іванович Свидюк, а слів - Василь Потавчук.

«Емоційна, імпульсивна, рішуча і категорична, а тому неоднозначна», - такою залишилася Нонна Михайлівна у теплих згадках Сподарця В. І., кандидата філологічних наук, доцента кафедри української філології і методики навчання фахових дисциплін Південноукраїнського національного педагогічного університету ім. К. Д. Ушинського, який пам'ятає Нонну Михайлівну ще за часів іiі роботи заступником декана філологічного факультету.

Кандидат філологічних наук, доцент кафедри теорії літератури та компаративістики Чернявська Д. С. повідомила про найвизначніші «вояжі долі», які назавжди пов'язали іï із Нонною Михайлівною як 3 близькою подругою і рідною людиною.

Конструктивну роботу секційних засідань організовували головуючі, зокрема, кандидат філологічних наук, доцент, завідувач кафедри української літератури О. Г. Шупта-В’язовська, кандидат філологічних наук, доцент кафедри світової літератури А. Т. Малиновський, доктор філологічних наук, професор, завідувач кафедри прикладної лінгвістики Н. В. Кондратенко, кандидат філологічних наук, доцент кафедри української літератури Т. М. Шевченко, доктор філологічних наук, професор кафедри світової літератури В. Б. Мусій, доктор філологічних наук, професор, завідувач кафедри загального та слов'ян- 
ського мовознавства О. А. Войцева, доктор філологічних наук, професор, завідувач кафедри російської мови $Є$. М. Степанов.

У процесі жвавого діалогу дискутувалися актуальні проблеми сучасного літературознавства: теоретико-методологічні засади досліджень літературної антропології, висвітлені доктором філологічних наук, професором кафедри світової літератури Н. В. Сподарець; аспекти вивчення генологічної природи ліричної прози, окреслені кандидатом філологічних наук, доцентом кафедри української літератури О. В. Казановою; питання химерної природи прози О. Стороженка, актуалізовані кандидатом філологічних наук, доцентом кафедри української літератури Л. Д. Чикур; акценти поетики збірки О. Гріна «На хмарному березі» як художнього цілого, проаналізовано кандидатом філологічних наук, доцентом кафедри світової літератури Т. Ю. Морєвою; форми виявлення і роль художніх емоцій в українському історичному романі, визначені кандидатом філологічних наук, доцентом кафедри теорії літератури та компаративістики О. О. Мізінкіною.

Глибокою аналітичністю було позначена доповідь кандидата філологічних наук, доцента, завідувача кафедри світової літератури Н. М. Раковської про критичні рефлексії Р. Барта в рецепції сучасного літературознавства та виступ кандидата філологічних наук, доцента кафедри української літератури Шевченко Т. М., в якому увагу було зосереджено на жанрово-стильових відлуннях європейських і східних есе у творчості сучасних українських письменників.

Новаторським поглядом на місце образу стихій у творенні картин ментального простору в оповіданні О. Толстого привернула увагу присутніх доктор філологічних наук, професор кафедри світової літератури В. Б. Мусій. Цікавими для слухачів виявилися повідомлення кандидата філологічних наук, доцента кафедри світової літератури С. О. Фокіної щодо підтексту ліричного сюжету поезії А. Ширяєва, кандидата філологічних наук, доцента кафедри теорії літератури та компаративістики О. О. Подлісецької щодо питання про інтерпретаційні моделі прози Лесі Українки, кандидата філологічних наук, доцента кафедри світової літератури О. Ю. Добробабіної стосовно поетики сюжету повісті Л. Толстого «Диявол»; кандидата філологічних наук, доцента кафедри української літератури Л. Б. Мостової, яка розкрила художні особливості світу сучасної української казки. 
Проблеми міжмистецької взаємодії порушили у своїх доповідях доктор філологічних наук, професор кафедри української літератури Н. П. Малютіна та кандидат філологічних наук, доцент кафедри української літератури I. В. Нечиталюк («Привласнення часу мистецтвом фотографії та перформатизація публічного перебування в музеї»); кандидат філологічних наук, доцент кафедри теорії літератури та компаративістики I. I. Томбулатова («Великий Гетсбі»: музика у тексті Фіцджеральда та саундтрек до фільму Лурмана»); кандидат філологічних наук, доцент кафедри болгарської філології О. Ю. Сайковська («Різновиди трансгресивності у творах Павела Вежінова»); кандидат філологічних наук, доцент, завідувач кафедри теорії літератури та компаративістики Н. К. Коробкова («Інтермедіальність: проблеми типології»).

Яскраву палітру досліджень із галузі сучасної лінгвістичної думки було представлено розвідками членів мовознавчих кафедр: кафедри української мови, яку представляли доктор філологічних наук, професор С. В. Форманова з доповіддю про функційну парадигму топонімів та кандидат філологічних наук, доцент М. Л. Дружинець, яка висвітлила основні проблеми сучасної теорії фонетичного символізму; кафедри російської мови, репрезентованої студіями кандидатів філологічних наук, доцентів Горбань В. В., Мальцевої О. В. та викладача Собченко Н. С.

Переконливими були доповіді колег з кафедри загального та слов'янського мовознавства: про польську культурно-марковану лексику (доктор філологічних наук, професор О. А. Войцева); символічні значення у ЗМІ (доктор філологічних наук, професор О. В. Яковлева); неофемінітиви в сучасній українській мові (кандидат філологічних наук, доцент Г. Ю. Касім); адаптацію новітніх запозичень (на матеріалі ЗМІ України) (старщий викладач Е. Е. Мінкевич).

Кафедрою прикладної лінгвістики було запропонувано увазі присутніх результати досліджень з кола проблем інтерпретації мовленнєвого впливу (кандидат філологічних наук, доцент Н. В. Кутуза); ритуального політичного дискурсу (кандидат філологічних наук, доцент Л. І. Стрій); міжкатегорійних зв'язків адресантності як визначального параметру художнього тексту (кандидат філологічних наук, старший викладач А. М. Кіщенко); синкретичних мовленнєвих жанрів агітаційного політичного дискурсу (кандидат філологічних наук, викладач Билінська О. С.). Основні засади концепції мовленнєвих 
жанрів М. Бахтіна в лінгвістичному висвітленні узагальнила і систематизувала доктор філологічних наук, професор, завідувач кафедри прикладної лінгвістики Н. В. Кондратенко.

Культурологічний аспект досліджень болгарських переселенських говірок висвітлила у своїй доповіді доктор філологічних наук, професор, завідувач кафедри болгарської філології В. О. Колесник.

Учасники конференції одностайно наголосили на високому науковому рівні доповідей студентів, магістрантів та аспірантів.

Наукові читання, присвячені пам'яті доктора філологічних наук, професора кафедри теорії літератури та компаративістики Нонни Михайлівни Шляхової, засвідчили іiї неоціненний внесок у розвиток української філологічної думки.

Відеозапис пленарного засідання можна подивитися за посиланням : https://www.youtube.com/watch?v=t-ThfK1LcPI\&t=12s

Наталія Коробкова

Стаття надійшла до редакиії 8 жовтня 2018 р. 